\title{
Rehumanizing the Archive, Mixtape by Mixtape
}

\author{
Mark V. Campbell \\ Keynote Address presented at the CAML conference, June 8, 2021
}

\begin{abstract}
Since at least 2007 archival practice has turned its attention to American hip-hop culture. In both ivy league universities and in less resource rich schools, hip-hop archives large and small are developing. A great deal of attention has been generated by institutions such as the Smithsonian and Cornell's Hip-Hop Collection, this is a good thing for a culture founded by racialized youth, often maligned by the dominant media. Yet, in more than a decade of archiving hip-hop culture, there remains a paucity of academic writing - this is a problem. In this talk I probe this paucity and reflect on my own practice of developing Northside Hip-Hop Archive. I argue that at stake in the archiving of hip-hop culture are the possibilities of dismantling the historical colonial underpinnings of the archival process. I turn to mixtapes as one way of exploring divergent means by which to archive hip-hop culture that might mitigate the long shadow of colonial archival practices.
\end{abstract}

\section{Résumé}

Depuis au moins l'année 2007, les archivistes s'intéressent à la culture hip hop américaine. Tant dans les grandes universités que dans celles ayant accès à moins de ressources, des archives hip hop de toutes les tailles voient le jour. Les collections hip hop des établissements comme le Smithsonian Institution et la Cornell University ont généré beaucoup d'intérêt, ce qui est une bonne chose pour une culture fondée par des jeunes racialisés, souvent dénigrés par les grands médias. Et pourtant, même si l'on archive depuis plus d'une décennie la culture hip hop, il existe peu de publications universitaires sur le sujet, ce qui est problématique. Dans ma présentation, je parle de cette rareté et je réfléchis à ma propre pratique consistant à développer la Northside Hip Hop Archive. J'avance que l'archivage de la culture hip hop offre l'occasion de démanteler les assises

\footnotetext{
Mark V. Campbell (mark.campbell@utoronto.ca) is a DJ, scholar, and curator. Dr. Campbell is currently the Principal Investigator in the SSHRC-funded research project, Hip Hop Archives: The Poetics and Potentials of Knowledge Production. His forthcoming books include the monograph AfroSonic Life, the co-edited collection of essays, Hip Hop Archives: The Politics and Poetics of Knowledge Production with Murray Forman (2022), and recently published We Still Here: Hip Hop in North of the 49th Parallel with Dr. Charity Marsh (2020). Dr. Campbell is Assistant Professor of Music and Culture at the University of Toronto Scarborough and Associate Chair of the Department of Arts, Culture and Media.
}

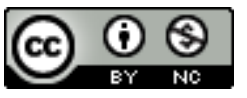

This work is licensed under a Creative Commons Attribution-NonCommercial 4.0 International License. 
colonialistes historiques du processus d'archivage. Je propose les compilations comme moyen différent d'archiver cette culture, car elles ont le potentiel de nous émanciper des pratiques archivistiques coloniales.

\section{Introduction}

Since at least 2007, institutional archival practice has turned its attention to American hip-hop culture. In both ivy league universities and in less resource rich schools, hip-hop archives large and small are developing. A great deal of attention has been generated by institutions such as the Smithsonian and Cornell's Hip-Hop Collection. This is a good thing for a culture founded by racialized youth, often maligned by the dominant media and mainstream institutions. Yet in more than a decade of archiving hip-hop culture, there remains a paucity of academic writing. This is a problem. In this keynote presentation I probe this paucity and reflect on my own practice of developing Northside Hip-Hop Archive. I argue that at stake in the archiving of hip-hop culture are the possibilities of dismantling the historical colonial underpinnings of the archival process. I turn to mixtapes as one way of exploring divergent means by which to preserve hip-hop culture that might mitigate the long shadow of colonial archival practices. By definition, mixtapes are cassette recordings of songs usually mixed together by a DJ and often distributed by street vendors, record stores, and individual DJs.

I begin from a place that centres Black cultural production and refuses to overdetermine what we know as preservation. Archives, as we all know, are deeply implicated in the colonial project and often represent a reification of existing social hierarchies so that one can trace the lingering influences of patriarchy, heteronormativity, and antiblackness in archival practices and collections. My job here today is to share with you some of the ways in which I imagine workarounds, emergent areas of scholarly possibility, and the general impact of hip-hop culture on the institutional practices of archiving. My interests lie in probing the elements of hip-hop culture to better understand how concepts of memory, preservation, and description might already be deeply embedded in the signifying practices of hip-hop's artforms, such as sampling, and DJing. I will first outline what I see as aspects of hip-hop culture that lend themselves nicely to concerns around preservation and heritage. Next, I drill down to two specific possibilities for imagining archival formats that diverge from the accepted mechanisms of archiving: DJ remixes and the mixtape. I end by returning to what is at stake in archiving hip-hop culture and what might be the areas of future foci to mitigate the colonial and antiblack violence embedded in colonial Europe's notion of preservation.

Throughout this talk, I move between discussing community-based archives that tend to have a DIY style, and the formal, institutionalized archives run by degree accredited Archivists. With the latter, I focus on the kinds of colonial inheritances and residues, especially with sound archives, that limit how we might imagine preservation, power, and knowledge production. Echoing the astute observations of Schwartz and Cook, I am attentive to the presumed objectivity and neutrality 
imagined to be at the core of the archival sciences. ${ }^{1}$ While with community archives, I focus on their possibilities for providing new and useful "problems" that might influence transformations in the archival sciences and institutional, bricks and mortar archives. Community archives, with their DIY sensibilities and amateur expertise are useful sites of innovation that amplify the limits of the archival sciences. ${ }^{2}$ True to my training as a DJ, I am actually more invested in a constant movement between these two archival concepts and practices. I think they both can benefit from being mixed together to generously inform one another.

\section{Hip-Hop's signifying practices and preservation}

A focus on archiving hip-hop culture can mean more than accounting for influential figures and leaders. A focus on artistic practices helps us move away from individualized, hero narratives steeped in enlightenment era notions of autonomy and devoid of the actual community that nurtured the artist's development. Central to how I wish to detail hip-hop's signifying practices is to start beyond the visual representations of hip-hop culture, denying a reifying ocular obsession with race. Instead, I focus on three sonic innovations within the culture: sampling, remixing, and mixtapes. But before I dive in, there are some more general aspects of the culture I should note that may help clarify my methodological choices. Hip-hop includes four primarily artistic elements: DJing, graffiti, breaking, and emceeing. These four elements of South Bronx culture were brought together and articulated as hip-hop in the 1970s. Most people unfamiliar with hip-hop culture are familiar with rap music, the most commodifiable of these four elements and the aspect of the culture that multinational record labels have been able to profit from. Rap, as one individualized, oral practice, has distinguished itself from other musical genres by relying on rhythmic flows, syncopated beats produced from pre-recorded samples of existing records, and also by its competitive rhyming structures that take the African American practice of the dozens to new heights. Harsh in its social critiques of antiblack racism and general social inequality, rap music also distinguishes itself as having an internal critique structure which operates as a quality control mechanism, encouraging artists to reject wackness and biters (those who copy other people's style). Artists in other musical genres rarely regulate each other in this way, so that battles don't occur in country music, opera, house, jazz, or rhythm and blues. In the earliest days during Carnival, Chantwells were oral improvisators whose songs often involved criticizing the British colonial government. ${ }^{3}$ Early Chantwells, such as Hannibal, Mighty Panther, sang competitively extempo

\footnotetext{
${ }^{1}$ Joan M. Schwartz and Terry Cook, "Archives, Records, and Power: The Making of Modern Memory," Archival Science 2 (March 2002): 1-19.

${ }^{2}$ Sarah Baker and Alison Huber, "Notes Towards a Typology of the DIY Institution: Identifying Do-it-Yourself Places of Popular Music Preservation," European Journal of Cultural Studies 16, no. 5 (October 2013): 513-530.

${ }^{3}$ Kevin Burke, “Where Calypso Gone?” Caribbean Quarterly 66, no. 1 (March 2020): 29-49.
} 
calypsos during Carnival and were one of the few related competitive battles you will find in musical forms from this part of the world.

In this talk, I steer clear of the rhyming efforts of emcees to avoid how listening and reading race divert us from a focus on sonic innovations. Hip-hop music is created by sampling clips of existing records, providing an entirely new paradigm for musical creation. This technique involves rerecording a portion, usually a couple of seconds, of a song and looping the sample to produce an extended bed of music to rap over. Sampling was evident on the first commercially successful record, the Sugar Hill Gang's "Rapper's Delight" (1980). However, the technological development of the sampler and DJ Marley Marl's use of the 2.5 second sampling limit on the SP 1200 heralded a golden age of sampling in the late 1980s. By 1991, record labels began suing artists for copyright infringement. The landmark case of Grand Upright Music Ltd. v. Warner Bros Records Inc. focused on Biz Markie's use of a sample from Gilbert O'Sullivan's 1972 hit "Alone Again."

Sampling is more than merely using portions of existing recorded music to make new music. It also involves an ethic of research, as one moves through genres and generations of music to find the "right" sound. It makes good use of "old" (by industry standards) recordings from bygone eras, breathing life into the "dead." Sampling allows us to ask how Afrosonic life recuperates and reconstitutes itself in the face of legal restrictions. Such restrictions range from the numerous noise ordinances in colonial societies which banned the use of drums in Trinidad, Jamaica, Colombia, and several other colonies, to modern-day copyright laws that prohibit sampling. When viewed alongside a historical trajectory of outlawed musical and sonic innovations, sampling in hip-hop becomes more than just a violation of intellectual property rights; it unravels a code of legal workings which continue to circumscribe and deny Afrosonic expressions of subjectivities and the legal personhood of African-descended peoples outside of the equation of property rights. Sampling also exposes the limits of the Western cultural enterprise as unprepared to expand definitions of music and music-making invented by Afrodiasporic populations. More importantly, for our purposes today, sampling troubles our notions of provenance and disturbs how comfortable we have become with the notion of individual property rights. Rights are illogical for those stolen from their homelands and made into property. Members of the African diaspora know the nefarious lineages of insurance companies and banks; the humans who were made into property served the unnatural purpose of capital accumulation. The act of sampling provides us with a way to think about music and its ownership in creative terms beyond the value schema of the music industry or the intellectual property rights regime. As sampling refuses the logic of authorship or property ownership, it deciphers the codes by which regimes of property ownership attempt to commodify culture. Even when disciplined by courts and litigation, Afrosonic innovators continue to demonstrate they cannot be contained by the logic of the market or other contemporary forms of disciplinary forces and boundaries. 
When we think of hip-hop cultures and how their various artistic expressions and innovations induce specific behaviours, such as "misusing" a turntable to make music, then it becomes clear how the conception of hip-hop archives as warehouses of accumulated documents and facts does not suffice. In addition to grappling with the realities of social inequality in both traditional and digital archives, the stability sought by an archive in its naming and categorizing of its content is an awkward fit with ways in which hip-hop culture refuses to remain static. Sampling continually brings new music into conversation with older music in its genre borrowing practices, as "b-boy ciphers" and "freestyle sessions" focus on movement, change, and newness. ${ }^{4}$ Concepts of ownership are at odds with the flow, rupture, and remixing embedded in the many artforms at the core of hip-hop culture. For instance, an archival approach to Jay-Z and Kanye's 2011 track "Otis" encourages us to connect the musical genres of soul and hip-hop, two very different eras, 2011 and 1966. The five other samples used to compose "Otis," including a 1974 James Brown song, wording from a 1932 Serenity prayer, and dialogue from the 1988 film Coming to America, open up a field of potential interconnections in film, funk music, and prayer. At the very least, excavating these original samples begins to shed light on the ethic of "digging" at the core of hip-hop production Even this focus on the categorizing of samples does not begin to broach the dynamics of Kanye West's production skills; archiving of this particular song requires thinking about technique and the technical intricacies of sampling evidenced in the track.

The aesthetics and ethics of hip-hop production which offer us nuanced questions of form, style, and politics risk being overlooked when hip-hop is forced to fit within traditional archival structures. Unless they are immersed in hip-hop culture, archivists and librarians risk developing collections that will miss or fail to capture the innovative methods by which the dominance of racial schemas and discourses of marginalization are circumvented, reworked, or simply destroyed. To effectively reflect hip-hop culture, archives must move beyond narratives of black death, marginalization, and racial schemas to embrace and thoroughly investigate artistic practices which distinguish hip-hop as a cultural form.

To generously archive hip-hop, one needs more than simply an additive approach. Hip-hop archives cannot be reduced to a marginalized field that can simply be added on. Interpreting the practices of sampling, remixing, and mixtapes as hip-hop archival artifacts reveals how these practices challenge the existing codes, practices, and ideologies of colonial archives. They become testaments to a set of differences which reorder the white racial imagination and the reifying of Western power and knowledge.

\footnotetext{
${ }^{4}$ B-Boy ciphers involve highly improvised dancing circles in which b-boys and b-girls absorb the energy of the moment and take turns inventing various combinations of dance moves when entering the centre of the circle. Similarly, in freestyle battles, emcees improvise lyrics in competition with one another, relying on skill, humour, and criticism to defeat their opponent.
} 
Sampling, remixing, and mixtapes are practices within hip-hop culture which seep into an archive. They are artistic practices that resist silos and speak of localized black geographies, divergent notions of individual property rights, and oftentimes are at odds with the existing copyright regime. As sampling disrupts European notions of the author by embracing a notion of multiple authors, it also refuses a linearity central to European enlightenment's notion of progress. Often in sampling practices, as we saw with Kanye, Jay-Z, and Otis Redding, the past can become the future and the present does not seal itself off from its past. The art of sampling and remixing works within this logic to produce new sonic experiences and forms of art in friction with notions of individual property. Authorized remixes, such as those commissioned by record labels and those unauthorized remixes found on mixtapes and on radio shows, pose special challenges to archival description and attempts, especially as the obscurity of some hip-hop samples requires significant effort to uncover. Archiving authorized and unauthorized remixes in generous ways might be possible by leveraging the specialized skills of music librarians and archivists.

Remixing knits illegality, technological subversion, and musical experimentation together. With origins and antecedents in both disco music and dub, remixing is a core aesthetic feature of contemporary popular music, including hip-hop. ${ }^{5}$ Following Eduardo Navas's definition, remixing is "the activity of taking samples from pre-existing materials to combine them into new forms according to personal taste." ${ }^{16}$ Remixing has many similarities with sampling. Both refuse to accept the manufactured obsolescence of "old" music and both utilize existing recorded music in an effort to create new music. Remixes work through memory, nostalgia, and popular songs to recontextualize and reinvent a particular sound or song. Yet, as David Grunkel reminds us and as Biz Markie's failed court case demonstrates, remix artists and sampling practices are in clear violation of copyright laws. ${ }^{7}$

Although the practice of unauthorized sampling and remixing disturbs intellectual property concerns of Western economies and urges a re-evaluation of the notion of the author, the remix is a generative possibility within the archival sciences, providing the opportunity to link together songs, artists, and audio samples from disparate sources. Such linking of a hip-hop song or remix undoes narrow understandings of the genre and enhances the purview of researchers. Hypothetically speaking, assigning a data management system, developing a knowledge graph, and linking data across the web become possibilities to deal with remixes in archival collections and open up robust options to offer researchers a relational understanding of hip-hop's music production process. This potential archive of deep sonic connections already exists on sample focused websites such as whosampled.com, whose academic pro version boasts more than 400,000 songs. Further, linked data projects, such as Linked Jazz (http://linkedjazz.org/) feature a dedicated

\footnotetext{
${ }^{5}$ Michael E. Veal, Dub: Soundscapes and Shattered Songs in Jamaican Reggae Middletown (Middletown, CT: Wesleyan University Press, 2013).

${ }^{6}$ Eduardo Navas, Remix Theory: The Aesthetics of Sampling (Vienna, Austria: Springer, 2012), 65.

${ }^{7}$ David J. Gunkel, Of Remixology: Ethics and Aesthetics after Remix (Cambridge, MA: MIT Press, 2016).
} 
team of professional archivists working within the parameters of the library sciences. Hip-hop and popular music's use of samples and remixing offer the archival sciences the interesting challenge of discovering and linking a diverse array of samples. For example, it was not uncommon for the production team behind Public Enemy's music, the Bomb Squad, to utilize hundreds of samples on one album. The implications for archiving this work are daunting. ${ }^{8}$ Bringing an archival sensibility to sampled and remixed work might mean linking these songs to their originally sampled songs, and expanding or disrupting categories like genre, time period, and author.

Scholars in the early 2000s focused on the illegality of sampling or remixing on the infringement aspect of remixing. ${ }^{9}$ Their focus on copyright misses the affective impact which induces hip-hop artists to step outside the binary of legal and illegal artistic production-the legally sanctioned language of artist and creative. Copyright transformed the recorded album and placed on centre stage the DJs and their various technical innovations and abilities.

Samples that have not cleared copyright, and more specifically remixed music, trouble and make ambivalent the concept of the author, a central linchpin in organizing music for market consumption. With Barthes debating the death of the author in 1967 and Foucault wondering in his 1969 lecture "What is an Author?" the remix's troubling of the concept of the author in the digital era is ripe with potential. ${ }^{10}$ Troubling the concept of the author disrupts the hegemony of the cultural industries to organize, stifle, and control artistic and cultural production. DJs in disco and dub more than a decade prior to hip-hop have been creatively destroying the authority and power of the author, creating the kinds of dancefloor (and boardroom!) chaos that allows artists to delve deeper into their creative reservoirs and invent music geared towards audiences rather than solely towards industry.

\section{The Unauthorized \& Ephemeral Remix + Mixtapes}

With the advent of mixtape, DJs regularly remixed songs and distributed them on cassette. On mixtapes, unauthorized remixes were artistic statements by DJs, often either loosely connected or entirely disconnected from the infrastructure offered by record labels. Infrequently, DJ remixes

\footnotetext{
${ }^{8}$ Kembrew McLeod, "An Oral History of Sampling: From Turntables to Mashups," in The Routledge Companion to Remix Studies, ed. Eduardo Navas, Owen Gallagher, and xtine burrough (New York, NY: Routledge, 2015$), 91$.

${ }^{9}$ See Lawrence Lessig, "Free(ing) Culture for Remix," Utah Law Review 4 (2004): 961; Lawrence Lessig, Remix: Making Art and Commerce Thrive in the Hybrid Economy (New York, NY: Penguin, 2008); Graham Reynolds, "A Stroke of Genius or Copyright Infringement: Mashups and Copyright in Canada," SCRIPTed: A Journal of Law, Technology and Society 6, no. 3 (August-December 2009): 639.

10 John Logie, "Peeling the Layers of the Onion: Authorship in Mashup and Remix Cultures," in The Routledge Companion to Remix Studies, ed. Eduardo Navas, Owen Gallagher, and xtine burrough (New York, NY: Routledge, 2015), 306-19.
} 
found on mixtapes and thus often unauthorized become licensed and authorized recordings. The DJ Ron G remix of Mary J. Blige's "Be Happy" is one of these infrequent moments. ${ }^{11}$ Although unauthorized remixes in hip-hop culture sit at the edges of legality and thus pose challenges to their fit in institutionalized archives, there are a couple of ways to reimagine the unauthorized remix. First, remixes such as the More Love project sample material that is too costly to get cleared. A project such as this is built around the hugely successful careers of Drake and Sade. Obtaining clearance to sample or remix these works from record labels is a long and potentially expensive endeavour with the existence of no standard rates to use sampled materials. DJs and producers are at the whim of individual labels and their lawyers, so that even an estimated cost of clearing samples is an unregulated and subjective endeavour. More Life features the use of both Sade and Drake vocals over instrumentals that do not belong to each of these artists. This mixtape created by DJ Vacations features five tracks which alternate between Sade and Drake vocals, mashing together themes and concepts from each artist and titling each song as a riff on original song titles. ${ }^{12}$ For example, a track titled "Can't Cherish Everything," is a mashup of Sade's iconic "Cherish the Day" with Drake's lyrics on "Can't Have Everything." These five tracks provide an unfiltered window into artists' creative impulses that are not in relation to a record label's market driven desires but more reflective of the creative and artistic priorities of DJ Vacations. These samples, even when violating copyright, actually develop and expand audiences, particularly of young people who are building collections of music already bound by the algorithmic regimes of Spotify and Apple Music.

Remixes, and especially mashups, encourage a less rigid notion of genre, highlighting the role of industry in organizing how we engage and consume music but also illuminating the social fabrication of these categories. By being more generous with categorizing music, embracing a sense of multiplicity might seem to go against the notion of a category, but does open up more ways for researchers to analyze music in both institutional and community-based music archives. Black musical forms do not always lend themselves to genre classification in any neat way; this slippiness can frustrate researchers who dig through institutional archives. For both community/DIY archivists and institutional archivists diverting from the categories assigned by the music industry might prove useful, not just for those interested in disrupting the logic and metrics of record labels and the music industry but also for those artists and non-academic researchers invested in other kinds of non-commercial perspectives and possibilities.

Part of the "good trouble" remixes create is that they provide a clear line of sight to Europe's limited and provincial notions of culture which form the basis of the creative industries. Every remix, such as the more than 200 versions of songs using the "Under Mi Sleng Teng" riddim produced by Jamaican producer and former Toronto resident Prince Jammy, signals artistic and

\footnotetext{
${ }^{11}$ DJ Ron G was one of the earliest remix innovators in New York City's robust mixtape scene. He has been called the "Remix King" by notable scholar Jared Ball.

12 More information on the More Love mixtape can be found at https://www.datpiff.com/Drake-x-Sade-MoreLove-mixtape.846124.html.
} 
aesthetic ideals that neither validate nor reproduce the values and tastes of middle-class Europe. The musical genres, recording production techniques, and sonic innovations from Jamaican sound system culture do not reference Europe in its ontology. As Dick Hebdige made clear in his 1987 book, Cut ' $n$ ' Mix: Culture, Identity and Caribbean Music, "nobody owns sound." ${ }^{13}$ European values of property ownership do not hold the same weight in the sonic realm, and one could argue that the sonic and the oral have been primary arenas that continuously reject the notion of individual property rights and the values embedded in European enlightenment thought, such as autonomy. The antecedents of remix culture, emanating from Jamaican sound system experiments and American disco clubs, never rested neatly within the existing paradigms of culture legally enforced by governments.

The practice of remixing embraces difference, otherness, and the past, and is embedded within a copyright regime whose goal is to "promote the progress of useful arts." ${ }^{14}$ Remixing reflects a modality of human behavior (by DJs and producers) that pivots on a paradigm of value divergent from the music industry and the intellectual property rights regime. It is therefore essential that archives collecting hip-hop mixtapes, remixes, and source samples attend to how these works transform black cultural life, or disrupt mainstream/dominant culture, or risk black death in the archive, historically the role of this colonial institution in Black life.

\section{The Mixtape}

Mixtapes arose out of the numerous innovations of hip-hop culture in the mid 1970s. Emanating out of hip-hop, mixtapes became part of how new music was circulated and how DJs promoted their skills, originally within hip-hop but eventually expanding into other genres like jungle, house, and R\&B. Mixtapes are interesting because they cross many thresholds: as marketing tools for labels, as a DJ's business card, and at times as a courting tool in relationships. They are ephemeral and often are treated with minimal care and with little resale value. As an archival format, mixtapes embody ephemeral aspects of hip-hop culture such as vernacular, spoken word/broadcasting techniques as well as DJing techniques. Most importantly, mixtapes are home to unauthorized remixes and expose us to interesting/unauthorized sampling as a hotbed of copyright infringement. As almost all mixtapes were not authorized by record labels, except for the notable few in the Canadian context where DJ Mastermind's Street Legal Vol. 50 was released by Virgin Records and Baby Blue SoundCrew's Private Party Collector's Edition was released by Universal Records. The 1999 mixtape bust in Toronto, in which record shops had their mixtapes confiscated and were

\footnotetext{
${ }^{13}$ Dick Hebdige, Cut 'n Mix: Culture, Identity and Caribbean Music (New York: Routledge, 2003), 130.

${ }^{14}$ U.S. Copyright Office “Copyright Law: Preface." As cited in John Logie, "Peeling the Layers of the Onion," 299.
} 
charged with distribution of copyrighted materials, evidenced the increasing popularity of mixtapes in this city. ${ }^{15}$

This tension of the illegality of mixtapes obscures the other ways in which they might be important to a music scene: the development of DJs and their audiences and the sonic innovations embedded in these cassettes. For example, Marisa Parham's analysis brings us closer to understanding the intimate connections between mixtapes and sampling as she describes "the DJ using two turntables to disaggregate songs into discrete soundbytes so that they might be used as if they were digital, isolating out samples and breaks so that old texts could be made newly resonant with always present futures." ${ }^{16}$ DJs offer much in the way of theorizing music outside of the constraints of what ethnomusicologist Michael Veal calls "Westernized musical thinking." ${ }^{17}$ Archivally, mixtapes offer much more than the content of the songs recorded on the cassette or compact disc. They exert significant influence on their local communities, such as building a scene or increasing exposure for local artists. The aesthetic innovations of each mix hold the potential to dislodge audiences from a linear market orientation of new songs and reinforce an audience's sense of place and belonging by celebrating a specific locale or region or introducing new techniques to the aspiring DJs and producers.

I will examine aspects of three different mixtapes, focusing on how they speak to concerns around preservation and the priorities of archivists, both in institutions and in community archives. Further, I will suggest that the way we envision the preservation of Afrosonic innovations, such as sampling, remixes, or mixtapes, may lead to a more thoughtful archival practice to come.

\section{Soul Controllers Reggae Meets Hip-Hop vol. 8}

In the eighth edition of their wildly popular Reggae Meets Hip-Hop mixtape series, Toronto DJ crew the Soul Controllers offered an exemplary remix mixtape. Focusing on their award-winning Reggae Meets Hip-Hop series helps us grasp the influence of the riddim method in the Caribbean diaspora. ${ }^{18}$ In 2003, the Soul Controllers won a Justco Award for their mixtape Reggae Meets Hip-

\footnotetext{
${ }^{15}$ Celine Wong, “Toronto Stores Raided for Mixtapes," Rolling Stone Magazine, (October 7, 1999), https://www.rollingstone.com/music/music-news/toronto-stores-raided-for-mixtapes-76641/.

${ }^{16}$ Marisa Parham, "Sample | Signal | Strobe: Haunting, Social Media, and Black Digitality," in Debates in Digital Humanities 2019, ed. Matthew K. Gold and Lauren F. Klein (Minneapolis, MN: University of Minnesota Press, 2019), 104.

${ }^{17}$ Veal, Dub: Soundscapes and Shattered Songs, 16.

${ }^{18}$ For more on the riddim method, see Peter Manuel and Wayne Marshall, "The Riddim Method: Aesthetics, Practice, and Ownership in Jamaican Dancehall," Popular Music 25, no. 3 (October 2006): 447-70.
} 
Hop Vol. 8, shining a light on their innovative mixing abilities and remixes in which three black musical genres were blended and remixed into one avant-garde sonic experience.

In a completely different direction than many mixtapes, which often promote new singles, the series Reggae Meets Hip-Hop distinguished itself by focusing on bending (mixing) and blurring the boundaries between hip-hop, R\&B, and reggae music. Each mixtape volume included a variety of instrumentals from all three genres, mixed with vocals from a different genre in unpredictable and previously unheard ways. Blending the instrumental and a capellas of these various genres, the Soul Controllers extended and evolved the riddim method by mixing multiple instrumental tracks under a capella vocals, a complete inversion of this DJing technique.

The Soul Controllers start off the mixtape with reggae superstar Beenie Man's lyrics from "Row Like a Boat" mixed into the instrumental for Beyonce's "Crazy in Love" which runs for approximately 30 seconds before a new instrumental is introduced. Unlike the riddim method, in which the continuity of the same riddim plays for an extended period of time, the Soul Controllers maintain the vocals of the track and mix in another instrumental. Beenie Man's "Row Like a Boat" a capella is made to flow over seven different instrumentals as the Soul Controllers continuously blend successful instrumentals into the mix. In the diaspora, without direct access to the plethora of artists who might add their voices to a riddim in the Jamaican context, the digital copy of an a capella is made to suffice. The compositional strategy of Volume 8 flips the riddim method, promoting the DJ's mixing skills and song selection by frequently switching the instrumentals while maintaining one artist's lyrical flow. The shortened length of each instrumental added to the mix, sometimes lasting a couple of seconds, urges the audience to attune itself more fully to the voice element of the song, which remains constant as instrumentals are frequently changed.

From an archival perspective, the historical timing of the mixtape is significant, and if we are to take seriously the completeness of a sound archive item, as Sergio Canazza suggests in his concern for ethnic sound archives, two considerations should accompany this mixtape's description in an archive. ${ }^{19}$ The previously mentioned mixtape raid of October 1999 meant the Soul Controller's mixtape innovations occurred despite the heightened awareness of mixtape's illegality. Volume 8, arriving four years after the mass disappearance of mixtapes in Toronto, provides important context for the sound crew's success, which clearly reached beyond Toronto's borders. Secondly, the quickness of mixes, the precision of a capella voicings, and the timing of the entire mixtape composition were achieved beyond the merely analogue technologies available in 2002 and 2003. CD mixers were not widely popular with hip-hop DJs, so when a hip-hop DJ mixed a vocal into a track faster than could be cued using a stylus, it becomes clear that a mixture of analogue and

\footnotetext{
${ }^{19}$ Sergio Canazza, "The Digital Curation of Ethnic Music Audio Archives: From Preservation to Restoration," International Journal on Digital Libraries 12, no. 2-3 (August 2012): 121-35.
} 
digital technologies were being leveraged. The kinds of innovative mixes achieved before the arrival of industry standard digital vinyl systems, Serato and Tracktor, are exemplary and should be noted.

\section{From Toronto to the T-Dot}

In my own crew's mixtape from 1999, one lost to the mixtape bust, there exists a way to capture and articulate how sonic innovations indebted to Jamaican sound system culture evolved in the Toronto context. Titled T-Dot's Tightest, the project was conceived both as homage to local talent (always in the shadow of American media imperialism) and as a promotional tool of my up-andcoming sound crew. At the time, Canadian hip-hop artists were producing high-quality music and collaborating with talent in the American South, but in our minds, we still had much to prove. Thus, our contribution, as we saw it, was to create a mixtape that only featured Toronto artists. At the time, we had a weekly radio show at CHRY 105.5FM. We received all the promo records for the clubs and often bought much of the locally produced vinyl or had the show serviced with Canadian content. Our CRTC minimum-mandated Canadian talent of 35\% was often not reached regularly on our shows. Individual DJs' open format selection sought to avoid repeating the same tracks each week. ${ }^{20}$ Playing Canadian music was the DJ's prerogative and as aspiring tastemakers our agreement on the best local tracks meant we played specific tracks and did not play many others.

On T-Dot's Tightest, a cassette that did not win any international awards or local attention, there still exists much nuanced analytical possibility despite its being literally erased from stores. I want to draw attention to an extension of the Jamaican dubplate system and the way in which DJing techniques can be archived. To open the B-side of the cassette, we asked two local emcees to do a dub of a very popular Beatnuts track called "Off the Books" released in 1999. These emcees, Monolith members, Grimace Love and Spidahman, rhymed over the Beatnuts instrumental. In classic dubplate fashion their rhymes praised around our sound crew similarly to how reggae artists cut an original track for a sound system. ${ }^{21}$ This technique involves mimicking much of the same styling as the original track and adding phrases and words that detail the specialness of the DJ or sound system. Without access to digital editing software, we booked time at private studios in Toronto's Beaches neighbourhood and paid an hourly rate.

The dubplate technique has been central to the development of the Jamaican music scene. Across a number of genres, including lovers of rock, dub, and dancehall, the dubplate process has been one of the more unique aspects of the island's musical culture. At the time, we did not see the dub we recorded as an aberration of a Jamaican tradition but regarded it as an extension and a core part of

\footnotetext{
${ }^{20}$ In Canada, the CRTC is a federal organization that dictates how much Canadian content should be played by broadcasters. Amongst the ministry's many concerns, it is safe to say the protection Canadian identity and its celebration are long-standing (decades-long) concerns.

${ }^{21}$ Joshua Chamberlain, "So Special, So Special, So Special: The Evolution of the Jamaican 'dubplate', "Jamaica Journal 33, no. 1-2 (December 2010): 20-28.
} 
defining ourselves as a sound crew. I mention these behind-the-scenes nuances to help us think about archival description and categorization that align with the ideas and values that are part of Black musical cultures--hip-hop and reggae in this specific context. What this might mean is imagining sonic innovations as a potential way to organize and search for materials which might not neatly fall into existing categories, categories that are generic enough to provide wide applicability but far too narrow to be attentive to musical practices outside the European imagination. The metadata strategies around capturing dubplates in an archive are yet to be imagined.

One other aspect of our T-Dot's Tightest cassette is the element of DJ scratching found on multiple sections of the project. Listening carefully to the transition mixes and the DJ scratch techniques opens up organizational categories that could make it easier to search for these techniques in an archival collection. Further, for those learning to DJ or analyzing DJ compositional structures, the analogue capabilities of vinyl recordings captured on cassette demonstrate how specific scratches, such as transformer, baby scratches, and stabs, are, in their intensities and various velocities, historical markers (B-Side Track 3). With digital DJ interfaces becoming an accepted standard after 2006, the quickness of a capella remixes, mixed transitions, and scratching rapidly increased. Compositional strategies and the demonstration of scratching techniques on mixtapes transform dramatically, as foreshadowed in Vol. 8 of the Soul Controllers Reggae Meets Hip-Hop mixtape series. The DJ decides to end track two using an echo fade technique and brings back the introductory bars of track three. He utilizes repetition by bringing back the lyric "LA to Toronto" on the Saukrates' collaborative track with LA's Xzibit, "Keep it Movin,'” relying on manually rewinding each vinyl recording and timing the release of the cross fader. These techniques are very much the analytical terrain of DJs with lived experience of working with vinyl recordings and should not be excluded from the archival record.

\section{Black Death in the Archive: DJ Screw}

In Houston in the late 1990s, DJ Screw was reaching the pinnacle of his career after producing hundreds of mixtapes for nearly a decade. DJ Screw produced individual mixtapes when requested by a member of his community. Individuals requested mixtapes for special graduation celebrations, as gifts for someone special, and for inclusion of their own music within a mix with other artists. ${ }^{22}$ DJ Screw became known for his unique skill for mixing records, a technique referred to as "chopped and screwed." His method involved slowing two copies of the same record down so that the pitch and tone of the song became almost unrecognizable. The result of DJ Screw's chopped and screwed technique is that commercial radio songs often optimally created to be around three and a half

\footnotetext{
${ }^{22}$ Lance Scott Walker, “DJ Screw: A Fast Life in Slow Motion," Red Bull Music Academy (May 20, 2015), https://daily.redbullmusicacademy.com/2015/05/dj-screw-feature.
} 
minutes became five- and six-minute-long affairs. ${ }^{23}$ The slower pace of his mixtapes became legendary in Houston and much of the American South and worked to loosen a direct industry connection between DJ Screw's mixtapes and the market-orientated desires of record labels that sought to capitalize on the DJ's massive popularity. Like the art of sampling, DJ Screw's mixtapes-and mixtapes in a much more general sense--refuse a chronology and linearity that does not meet a DJ's aesthetic choices. The past, present, and future are reshaped by the DJ whose desire to reengineer time, sound, and music speak to a sense of agency and creativity fostered by hip-hop's subversive sonic explorations.

One can only speculate about the kinds of behaviour-inducing effects of DJ Screw's mixtapes or a Pete Rock sample, but it is in this speculation where Black life's audibility becomes productively disruptive. ${ }^{24}$ Outside of market time, beyond the optimal three minute and 40 second length of popular music, audiences sought aural pleasure unaligned with the dominant culture's desires for consumption. DJ Screw's mixtapes, often produced as one-offs, resisted a mode of commodification that reflected the mainstream music industry but not regularly producing duplicates, and by decidedly transforming the pitch and tempo of the songs he mixed on his cassettes. ${ }^{25}$ DJ Screw's practice of creating "chopped and screwed" mixtapes and his refusal to sign multiple record deals suggests his engagement in hip-hop culture was more than a tactic to gain entry into mainstream society..$^{26}$ Until his untimely death in 2000 , DJ Screw produced more than three hundred mixtapes, many of them one of a kind, made-to-order cassettes at the request of community members. An archive of his mixtapes followed his death. The passing of several other members of the Houston hip-hop community eerily haunt the archival efforts in Houston, reminding us of the historical connections between black death and colonial archives.

Yet with hundreds of mixtapes in existence, fewer than two dozen are housed at the University of Houston's hip-hop archive. ${ }^{27}$ While such low numbers might appear to be a failure in building the University of Houston's hip-hop collection, there is a great deal more signified by this low number of holdings. In making mixtapes on demand and by distributing them hand-to-hand, DJ Screw

\footnotetext{
${ }^{23}$ Mathew K. Carter, "All Day in the Trey-Fold: Sound, Objecthood, and Place in the Mixtapes of DJ Screw," (PhD Diss., City University of New York, 2020), https://academicworks.cuny.edu/gc etds/3982/.

${ }^{24}$ Pete Rock is an iconic hip-hop producer whose influence on hip-hop music in the 1990s and 2000s has been immensely influential, with the late J Dilla citing him as an inspiration. Pete Rock rose to critical acclaim after completing high-profile (authorized) remixes for Public Enemy and House of Pain. In partnering with CL Smooth, Pete Rock formed a group called Pete Rock \& $\mathrm{Cl}$ Smooth and produced well received albums, Mecca \& The Soul Brother in 1992, The Main Ingredient in 1994, and the E.P. All Souled Out in 1991.

${ }^{25}$ Aram Sinnreich and Samantha Dols, "Chopping Neoliberalism, Screwing the Industry: DJ Screw, the Dirty South, and the Temporal Politics of Resistance," in Hip-Hop Theory: Time, Technology, and the $21^{\text {st }}$ Century, ed. R. Christopher (Minneapolis, MN: University of Minnesota Press, forthcoming).

${ }^{26}$ Walker, "DJ Screw: A Fast Life in Slow Motion."

27 This number was as of my visit to the archive in December 2019. There is a strong likelihood that more tapes have been added, as they are regularly being rediscovered by the public.
} 
refused aspects of the commercial music industry and the commodification (through mass production and replication) of his mixtapes. By remaining outside the music industry, DJ Screw cultivated a connection to his art, his locality, and his fans that could not be undermined by the logic of the market and the practices of the industry. The hundreds of mixtapes not in the archive point to the human connections, built by DJ Screw's fiercely independent ways, that appear incompatible with the ability of an archive to collect, centralize, and make static these mixtapes that exceed commodity status.

The process of digitizing DJ Screw's mixtapes (both at the storefront and the university archive) is currently underway and presents opportunities to capture and archive aspects of hip-hop DJ aesthetics. Importantly, the storefront which sells DJ Screw memorabilia is also a site where his cousin, the store owner, digitizes old mixtapes at the store. Members of the public regularly walk into the shop with old cassettes, and the store develops the track listing, digitizes the cassette, and repackages it for sale. While somewhat obscuring the DJ's aesthetic legacy, this sort of aftermarket commodification of DJ Screw mixtapes, including the sale of drinks, t-shirts, and towels, demonstrates how far removed from the daily workings of the music industry DJ Screw chose to remain. Further, despite operating as a distribution outlet for DJ Screw memorabilia, the storefront, home to hundreds more mixtapes than the University's archive, also provides the opportunity for researchers and scholars like myself to view more than three hundred and forty playlists from the mixtapes on hand. In the digitizing and cataloguing of hundreds of mixtapes, in the case of DJ Screw or the Mixtape Museum, the opportunity exists for researchers to adopt practices from the digital humanities to explore how power, geography, gender, and race are situated within mixtape cultures.

\section{Conclusion: @ Stake in Archiving Hip-Hop}

The short description of these three mixtapes is not meant to be an exhaustive musicological investigation. Rather, these three cassettes are simply openings to further explorations of how archival work might reckon with Afrosonic innovations such as the riddim method, various DJ techniques, like "chopped and screwed," and the ways in which black death might haunt archival practice. Examined through an archival sensibility, mixtapes, sitting adjacent to the recording industry, can be thought of as historical counternarratives to the dominance of the commercial music industry. ${ }^{28}$ Through their innovative DJ techniques, distribution methods, and remix practices, mixtapes in an archival sense can do much more than signal the legal boundaries of contemporary

28 Jennifer L. Morgan, “Archives and Histories of Racial Capitalism: An Afterword," Social Text 33, no. 4 (December 2015): 153-61. 
copyright regimes. The level of attentiveness called for here is one way to continue to humanize the archival sciences in ways that mitigate antiblackness and offer new strategies to preserve Black life.

Given histories of colonialism, death, and the exercise of power via state and other institutional archive, hip-hop archives cannot be imagined as neutral storehouses of "facts" and documents about hip-hop cultures. Instead, hip-hop archives need to be imagined as homes to the possibility of counternarratives, sites where we can, according to Katherine McKittrick, "name the violent displacement of black cultures...."29 Accordingly, McKittrick believes "this must be done by both noticing and undoing the compulsion to inhabit safe and comfortable places within the very system that cannot survive without anti-blackness." ${ }^{130}$ As Ghaddar and Caswell advocate for a decolonial praxis within the library sciences, hip-hop archives sit on a precipice where knowledge production about Black and racialized lives is poised to emerge in an ethical justice-oriented fashion, if the digital humanities and archival sciences can decolonize itself into an intersectional field. ${ }^{31} \mathrm{Hip}$-hop archives, if operating through a decolonial praxis, as Ghaddar and Caswell urge, provide an opportunity to give Black life a different kind of future within the archives-a life whose multiplicity diverges from the singularity of racial representational regimes foisted upon the diasporic African. The proliferation of digital archives presents a promising opportunity to move away from the problems of access to brick-and-mortar archives, with "rogue" practices of collecting, remixing, and sharing archival materials, ignoring or rewriting some of the rules of archiving on the internet. ${ }^{32}$

Popular hip-hop music is easily detached from its local circumstances and packaged for national consumption. Posters, oral histories, and mixtapes are other items that reverberate with the pulse of a local scene-and they balance out the easily commodified status of music tracks, illuminating those historical figures whose contribution to hip-hop culture in their city does not translate commercially. If hip-hop archives can equally focus on all elements of the culture beyond the commercialized music known in American suburbs, this allows for a more holistic documentation and preservation of the culture. Such expansiveness might draw from artists whose influence or impact might not be tied to commercial, market, or national success or who may not be highly visible in consumer culture. Traditionally, archival preference has been towards those deemed highly influential, the powerful, or those victorious in struggles. Given these terms, it would be unlikely to find a celebration of a local hip-hop artist's legacy if they did not achieve national stardom. In some of the archival efforts at Tulane, University of Houston, Seattle, and the

\footnotetext{
${ }^{29}$ Katherine McKittrick, “Mathematics Black Life," The Black Scholar 44 No. 2 (Summer 2014): 19.

30 Ibid, 19.

${ }^{31}$ J.J. Ghaddar and Michelle Caswell, "'To Go Beyond': Towards a Decolonial Archival Praxis," Archival Science 19, no. 2 (June 2019): 71-85

${ }^{32}$ Abigail De Kosnik, Rogue Archives: Digital Cultural Memory and Media Fandom (Cambridge, MA: MIT Press,
} 2016). 
Massachusetts hip-hop archives, local artists are celebrated with equal vigour as mainstream stars, evolving the archival preference that privileges the dominant men of the past. ${ }^{33}$

When the glossiness of the popular does not become a centrepiece of a hip-hop collection, this allows for an analysis of more than the signifyin' practices of a local hip-hop community. It allows us to see hip-hop artists, especially those who resonate locally but not commercially (and thus internationally), as more than commodities feeding a market's desires. As Caribbean philosopher Sylvia Wynter urges critics to claim an "ethnic" or cultural tradition to "repress the dialectical nature of socio-culturally 'countering' aspects of the signifying practices of films themselves," hip-hop archives focused on their local scenes can assist in moving away from the dominant discourse's dialectical trap, of high/low brow, celebrity/nobody, powerful/marginalized which only serve to reproduce the status quo. ${ }^{34}$ Black humanity becomes audible and palpable when hip-hop culture attends to local environments and develops signifying practices that furnish a local context with more livable relations - a sense of "peace, love and having fun" in which aesthetic and creative labour dislodge the values of hierarchical ordering that pervade the ideologies that underpin the labour market.

A robust engagement with the possibilities of hip-hop culture potentially interrupting the violent classificatory systems that underpin the practice of archiving means drilling down to the myriad of unexcavated possibilities embedded in artistic practices of sampling, remixing, and mixtapes. Attention to hip-hop's hyperlocalness is one way to move beyond privileging the nation in archival practice, as we know the nation as a colonial formation has not been an innocent organizing tool, especially for racialized populations. Mixtapes, in their local circulation, allow us to grasp detailed moments and textures, in both analogue and digital realities, and can speak back to and against dominant narratives. If hip-hop, and the archives created to preserve this culture, might offer the archival sciences anything, it may be the opportunity for new modes of asserting and inserting Black living into how we archive.

\footnotetext{
33 See The NOLA Hip- Hop and Bounce Archive, https://digitallibrary.tulane.edu/islandora/object/tulane:p16313coll68; the Seattle Hip-Hop Archive, https://guides.lib.uw.edu/hiphop206; The University of Houston Special Collection, https://findingaids.lib.uh.edu/agents/corporate entities/12; and the Massachusetts Hip-Hop Archive, https://umb.libguides.com/hip-hop.

${ }^{34}$ Sylvia Wynter, "Rethinking 'Aesthetics': Notes Towards a Deciphering Practice," in Ex-iles: Essays on Caribbean Cinema, ed. Mbye B. Cham (Trenton, NJ: Africa World Press, 1992), 264.
} 


\section{References}

Baker, Sarah, and Alison Huber. "Notes Towards a Typology of the DIY Institution: Identifying Do-itYourself Places of Popular Music Preservation." European Journal of Cultural Studies 16, no. 5 (October 2013): 513-30.

Burke, Kevin. "Where Calypso Gone? Independence, Globalisation, and the Troubled State of Trinidad's National Music." Caribbean Quarterly 66, no. 1 (2020): 29-49.

Carter, Mathew K. "All Day in the Trey-Fold: Sound, Objecthood, and Place in the Mixtapes of DJ Screw." PhD Diss., City University of New York, 2020.

Canazza, Sergio. "The Digital Curation of Ethnic Music Audio Archives: From Preservation to Restoration." International Journal on Digital Libraries 12, no. 2-3 (August 2012): 121-35.

Chamberlain, Joshua. "So Special, So Special, So Special: The Evolution of the Jamaican 'dubplate'." Jamaica Journal 33, no. 1-2 (December 2010): 20-28.

De Kosnik, Abigail. Rogue Archives: Digital Cultural Memory and Media Fandom. Cambridge, MA: MIT Press, 2016.

Ghaddar, J.J., and Michelle Caswell. "To Go Beyond': Towards a Decolonial Archival Praxis." Archival Science 19, no. 2 (June 2019): 71-85.

Hebdige, Dick. Cut ' $n$ ' Mix: Culture, Identity \& Caribbean Music. New York, NY: Routledge, 1987.

Gunkel, David J. Of Remixology: Ethics and Aesthetics after Remix. Cambridge: MIT Press, 2016.

Lessig, Lawrence. "Free(ing) Culture for Remix." Utah Law Review, no. 4 (2004): 961-75.

Lessig, Lawrence. Remix: Making Art and Commerce Thrive in the Hybrid Economy. New York, NY: Penguin, 2008.

Logie, John. "Peeling the Layers of the Onion: Authorship in Mashup and Remix Cultures." In The Routledge Companion to Remix Studies, edited by Eduardo Navas, Owen Gallagher, and xtine burrough, 306-19. New York, NY: Routledge, 2015.

Manuel, Peter, and Wayne Marshall. "The Riddim Method: Aesthetics, Practice, and Ownership in Jamaican Dancehall." Popular Music 25, no. 3 (October 2006): 447-70.

McKittrick, Katherine. “Mathematics Black Life.” The Black Scholar 44, no. 2 (Summer 2014): 16-28.

McLeod, Kembrew. "An Oral History of Sampling: From Turntables to Mashups." In The Routledge Companion to Remix Studies, edited by Eduardo Navas, Owen Gallagher, and xtine burrough, 83-103. New York, NY: Routledge, 2015.

Morgan, Jennifer L. "Archives and Histories of Racial Capitalism: An Afterword." Social Text 33, no. 4 (December 2015): 153-61.

Navas, Eduardo. Remix Theory: The Aesthetics of Sampling. Vienna, Austria: Springer, 2012. 
Parham, Marisa. "Sample | Signal | Strobe: Haunting, Social Media, and Black Digitality." In Debates in Digital Humanities 2019, edited by Matthew K. Gold and Lauren F. Klein, 101-122. Minneapolis, MN: University of Minnesota Press, 2019.

Sinnreich, Aram, and Samantha Dols. "Chopping Neoliberalism, Screwing the Industry: DJ Screw, the Dirty South, and the Temporal Politics of Resistance." In Hip-Hop Theory: Time, Technology, and the $21^{\text {st }}$ Century. Minneapolis, MN: University of Minnesota Press, forthcoming.

Veal, Michael E. Dub: Soundscapes and Shattered Songs in Jamaican Reggae. Middletown, CT: Wesleyan University Press, 2013.

Walker, Lance Scott. "DJ Screw: A Fast Life in Slow Motion." Red Bull Music Academy, May 20, 2015, https://daily.redbullmusicacademy.com/2015/05/dj-screw-feature.

Wong, Celine. "Toronto Stores Raided for Mixtapes." Rolling Stone, October 7, 1999, https://www.rollingstone.com/music/music-news/ toronto-stores-raided-for-mixtapes76641/.

Wynter, Sylvia. "Rethinking 'Aesthetics': Notes Towards a Deciphering Practice." In Ex-iles: Essays on Caribbean Cinema, edited by Mbye B. Cham, 237-79. Trenton, NJ: Africa World Press, 1992. 